\title{
EL ENTERRAMIENTO EN LOS CEMENTERIOS, UN ASUNTO DE SALUD PRIORITARIO PARA LOS LIBE- RALES DE MALLORCA EN 1812
}

\section{BURIALS IN THE CEMETERIES, A CRITICAL MATTER OF HEALTH FOR THE LIBERALS OF MALLORCA IN 1812}

\author{
FeLIPE RodríGueZ Morín \\ Instituto Feijoo de Estudios del Siglo XVIII - Universidad de Oviedo \\ felipe.rodriguezmorin@asturias.org
}

Recibido: 19/7/2014

Aceptado: 30/11/2015

RESUMEN: Aunque a partir de 1787 se habían adoptado medidas legislativas prohibiendo enterrar a los muertos en las iglesias, diversos pretextos contribuyeron a que tal actividad persistiera en España hasta bien entrado el siglo XIX. Los liberales, dignos continuadores del espíritu ilustrado también en este su empeño de dar sepultura en cementerios fuera de las poblaciones, van a gastar muchos esfuerzos en intentar cambiar los viejos hábitos para adaptarlos a las exigencias de la ciencia y, en definitiva, al interés de la salud pública. Como muestra de esa labor, traemos aquí el ejemplo de lo sucedido en Palma de Mallorca después de que Miguel Domingo, editor del periódico que aglutinaba allí a los reformistas, la Aurora Patriótica Mallorquina, diera a la luz un escrito denunciando aquella anticuada praxis, originando con ello una extensa polémica en la prensa mallorquina.

PALABRAS CLAVE: enterramientos, cementerios, iglesias, salud pública, Miguel Domingo, Aurora Patriótica Mallorquina.

ABSTRACT: Since 1787, though several legislative measures had been adopted to forbid burials in the churches, due to different reasons, this practice continued in Spain until the 19th century. The liberals were deserving followers of the spirit of the Enlightenment, because they were supporters of burying on cemeteries outside settlements, and they were going to put a lot of effort into trying to change old habits in order to adapt them to scientific exigencies and, definitely, to the interest of public health. As a proof of that task, we bring here the example of something which happened in Palma de Mallorca, after Miguel Domingo, the editor of the newspaper that gathered the reformers, the Aurora Patriótica Mallorquina published a document where that antiquated custom was condemned, which caused a huge polemic in Majorcan press. 
KEYWORDS: burials, cemeteries, churches, public health, Miguel Domingo, Aurora Patriótica Mallorquina.

Como del propio título de este trabajo se desprende, el objeto del mismo se circunscribe de modo principal a dar noticia de la campaña que, fundamentada en motivos de salud pública, fue acometida por los liberales de Palma de Mallorca en favor de los enterramientos fuera de los recintos eclesiales. Dicha empresa, como tantas otras que en aquel período de las Cortes de Cádiz tenían por objeto modernizar España, se llevó a cabo de una manera más intensa a través de la prensa periódica, significándose de forma especial la cabecera liberal más señera de la isla: la Aurora Patriótica Mallorquina.

Como no podía ser de otro modo, esta iniciativa auspiciada por el sector reformista tuvo su oportuna contestación en la facción contraria, la de los serviles, quienes valiéndose igualmente del cauce periodístico, capitaneado por el $\mathrm{Se}$ manario Cristiano-Político de Mallorca, lanzaron su artillería verbal contra esta novedad, otra más que añadir al repertorio de cambios y mudanzas que, desde poco tiempo atrás, sacudían y amenazaban su mundo de certidumbres.

Tal planteamiento de la cuestión, centrado en reconocer el entusiasta empuje con que, a despecho de sus enemigos ideológicos, se emplearon tan significados liberales como Isidoro de Antillón y Miguel Domingo en defender la lógica de la salubridad frente a cualquier pretexto ajeno a ese fin, nos ha impedido detenernos, a pesar de su indudable interés, en el análisis de otros diversos condicionantes: religiosos o seudorreligiosos, culturales, sociales, económicos, etc., que consiguieron retrasar también la puesta en funcionamiento en nuestro país de los cementerios extramuros ${ }^{1}$.

\section{LAS VIEJAS PRÁCTICAS FRENTE A LA NUEVA MENTALIDAD}

Desde la Edad Media, se habían constituido las iglesias en los enclaves fundamentales para la práctica de los enterramientos, resultando lo más habitual

\footnotetext{
${ }^{1}$ La complejidad del fenómeno propició que llegaran a producirse situaciones tan extravagantes como las que nos relata Soledad Gómez: «Asimismo presentes en la cuestión de los cementerios, los significativos vaivenes al calor mismo, en movimiento prácticamente paralelo y como en otros casos, de vicisitudes higiénico-sanitarias y circunstancias políticas de las primeras décadas del ochocientos, que provocan, aun a veces en un mismo año y de forma intermitente, no solo traslados de lugar intramuros - parroquias, conventos, colegiatas, capillas o ermitas - a cementerio extramuros, de la iglesia al camposanto, en períodos de aperturismo y liberalismo, y de este a aquella en los de signo contrario, sino también retrasos en la definitiva terminación de aquel» (GÓMEZ NAVARRO, S. (1998). Una elaboración cultural de la experiencia del morir. Córdoba y su provincia en el Antiguo Régimen. Córdoba: Servicio de Publicaciones de la Universidad de Córdoba, p. 184).
} 
que estos se llevaran a cabo en el interior de las mismas o en sus atrios. Sin embargo, tal costumbre no dimanaba de ningún imperativo religioso; es más, en los comienzos del cristianismo y a lo largo de bastantes centurias nunca se había procedido de ese modo. Así lo sostiene, en los inicios del siglo XVIII, el capuchino fray Mateo de Anguiano: «es necesario que se entienda que la costumbre de enterrarse los Cristianos dentro de las Iglesias es muy nueva, generalmente hablando de todas partes, y particularmente en España; y tanto, que es de trescientos años o menos a esta parte ${ }^{2} \gg$. Y es que la situación inicial había comenzado a variar de forma paulatina, empezándose por dar sepultura en los recintos eclesiales, primero a los santos, más tarde también a reyes, obispos, grandes señores, etc., hasta que acabó, finalmente, por extenderse su uso y hacerse general.

La mayor parte de la población llegó a considerar que el hallarse los cuerpos de los difuntos depositados dentro del templo, mejor cuanto más cerca del altar, facilitaba la entrada en el cielo, al resultar, por la proximidad al Altísimo, más eficaces los sufragios por sus almas. Así lo explica Sarrailh: «Sabido es que era una regla consagrada por el uso el sepultar en el interior mismo de la iglesia, o en el atrio, muy cerca de ellas, los cadáveres de los fieles, colocados así bajo la protección inmediata de Dios, preservados de las visitas del demonio y siempre presentes a las oraciones y recuerdos de sus deudos ${ }^{3} »$.

De forma semejante formulaba este punto, con experiencias recogidas en su recorrido por las Baleares, el viajero francés Grasset de Saint Sauveur, en los tiempos en que tal hábito aún se mantenía: «On dit aux bons Minorquins, et ils le croient, que le dépot de leurs corps au pied d'un autel, assure, ou au moins facilite $l^{\prime}$ entrée de leurs ames dans le séjour céleste ${ }^{4} \gg$. Por su parte, Philippe Ariès ahondando en el tema, efectúa las siguientes precisiones: «El emplazamiento más buscado y más costoso es el coro, cerca del altar donde se dice la misa, allí donde el sacerdote recita el confiteor. Esa es la razón del enterramiento apud ecclesiam: el sacrificio de la misa, más que la protección de los santos [...]. Después del coro, el lugar más buscado era la capilla de la Virgen o su "imagen" [...]. Después del coro, la capilla o la imagen de la Virgen, se encuentra como lugar de elección de sepultura, a partir del siglo XV y también en el XVII, el crucifijo ${ }^{5} \gg$.

\footnotetext{
${ }^{2}$ ANGUIANO, fray Mateo de (1704). Compendio historial de la provincia de la Rioja, de sus santos, y milagrosos santuarios. Madrid: Antonio González de Reyes, p. 536.

${ }^{3}$ SARRAILH, J. (1974). La España ilustrada de la segunda mitad del siglo XVIII. México: Fondo de Cultura Económica (1 ${ }^{a}$ edición en francés: 1954, en español: 1957), pp. 49-50.

${ }^{4}$ GRASSET DE SAINT SAUVEUR, A. (1807). Voyage dans les iles Baléares et Pithiuses; fait dans les années 1801, 1802, 1803, 1804 et 1805. París: L. Haussman, París, p. 225.

${ }^{5}$ ARIÈS, P. (2011). El hombre ante la muerte. Madrid: Taurus (1 ${ }^{a}$ edición en francés: 1977, en español: 1983), pp. 93-95.
} 
Aparte de por estos presuntos beneficios para el perpetuo descanso del fallecido, el entierro en las iglesias cumplía otra misión, aunque también de carácter espiritual esta vez con un perfil más terreno, puesto que, sintiendo de cerca los fieles la muerte, y por ello la fugacidad de la vida, sin duda les procuraría un mayor deseo de arrepentimiento y de cercanía a su Salvador; así lo afirma Galán Cavila: «la presencia de la muerte en las iglesias era un instrumento didáctico encaminado a promover la devoción ${ }^{6} \gg$.

Sin embargo, todas estas razones para inhumar en las parroquias o lugares aledaños, siempre dentro de las poblaciones, se desmoronaban ante otros más poderosos argumentos en su contra, tal cual era el de la salud pública ${ }^{7}$. Pero por más que el sentido común empujaba a abandonar aquella praxis que hasta las leyes llegaron a prohibir en el último tercio del siglo XVIII, tardó en suspenderse su actividad bastante más tiempo que lo que fuera regular esperar en una orden sancionada por el rey; de manera que la utilización de los cementerios con carácter general no llegó a completarse en España hasta unas cuantas décadas después, esto es, cuando se hallaba ya bien adentrado el siglo XIX ${ }^{8}$.

El quid de la cuestión estribaba en que el cambio de lugar en las sepulturas no significaba solamente una mera modificación física del escenario9, sino que

${ }^{6}$ GALÁN CAVILLA, J. L. (1988). «Madrid y los cementerios en el siglo XVIII: el fracaso de una reforma», en Carlos III, Madrid y la Ilustración. Madrid: Siglo XXI de España Editores, p. 266.

${ }^{7}$ Del modo siguiente enuncia el asunto Michel Vovelle: «l'établissement des nouveaux cimetières, au nom d'arguments où la morale et la religion cèdent le pas à la salubrité» (VOVELLE, M. (1974). Mourir autrefois. Attitudes collectives devant la mort aux XVII e et XVIII esiècles. París: Gallimard/Julliard, se cita por la versión de Kindle, posición 3516).

${ }^{8}$ Acerca de este punto, María Pilar Brel destaca un año concreto: «La fecha clave en la puesta en práctica de la reforma fue 1833: el temor a la epidemia de cólera, presente en Portugal, impulsó de nuevo la construcción de cementerios: en ese momento coincidió la insistencia de las autoridades civiles, la buena disposición de las eclesiásticas y el temor de la población, por lo que la renovación y ampliación de los cementerios tuvo un decisivo empuje. Todas las ciudades grandes que carecían de él lo construyeron y también numerosos pueblos pequeños» (BREL CACHÓN, M. P. (1999). «La construcción de cementerios y la Salud Pública a lo largo del siglo XIX». Studia Zamorensia, nº 5, pp. 155-195, p. 167).

${ }^{9}$ Peral Pacheco opina sobre el particular que: «El hecho de que los cementerios pasen a estar intramuros a extramuros de las ciudades, significa no solo una variación en la ubicación de un edificio, sino que debió suponer la incorporación de ideas nuevas que debieron debatirse contra intereses circunstanciales por un lado y de otra parte vencer la inercia» (PERAL PACHECO, D. (1991-1992). «El cólera y los cementerios en el siglo XIX». Norba. Revista de Historia, 11-12, pp. 269-278, p. 269). Bastantes años antes, Vovelle ya había recogido ese paralelismo existente entre el distinto emplazamiento para llevar a cabo los enterramientos y una nueva concepción sobre el propio hecho de morir; fenómeno este que se experimentó en Francia a partir del último tercio del siglo XVIII: 
acarreaba, aparte de una intromisión en los intereses de una minoría (especialmente de los sacerdotes que celebraban los ritos religiosos relativos a los difuntos y a sus familias), una alteración profunda en el sentimiento de muchas gentes sencillas, puesto que, como anota Collado Ruiz, «la salud corporal de los vivos, se convirtió en detonante de una nueva práctica funeraria, que en esencia, acabó significando un exilio forzoso de los muertos ${ }^{10} \gg$.

Como tantos otros pasos adelante en la modernización del país, este de trasladar los cadáveres de los templos a los cementerios fue hijo, también, del siglo ilustrado ${ }^{11}$. Por eso, la amenaza de enfermedad $\mathrm{o}$, incluso, muerte, que aquel hábito suponía para la población será causa suficiente para abogar por su supresión, pues no se atisbaba ninguna causa lógica que permitiera defender su continuidad. Los viejos tabús, religiosos o del tipo que fueran, debían comparecer y disiparse ahora ante la luz iluminadora de la razón. Por si fuera poco, lejos de resultar ajeno a tales planteamientos, precisamente este asunto que ahora nos ocupa resultaba una especie de divisa para los defensores de los nuevos postulados, puesto que, en palabras de Granjel y Carreras, «el pensamiento que animaba a los ilustrados europeos hizo de la campaña contra los enterramientos en las iglesias un símbolo de la lucha de la razón contra la ignorancia y los prejuicios seculares ${ }^{12} \gg$.

«du charnier à l'église, au cimetière enfin, refoulé à partir de la fin du XVIII e hors de la vue des vivants, et cependant objet du transfert et de la fixation du nouveau culte des morts» (VOVELLE, M. (1975). «Les Attitudes devant la mort, front actuel de l'histoire des mentalités». Archives de sciences sociales des religions, nº 39, pp. 17-29, p. 26).

${ }^{10}$ COLLADO RUIZ, M. J. (2013). «La salida de los enterramientos de las iglesias hacia los cementerios extramuros en la capital granadina. Un largo y difícil proceso». Tiempo y sociedad, $\mathrm{n}^{\mathrm{o}} 12$, pp. 138-163, p. 139. Por su parte, Peral Pacheco se pronuncia de muy similar manera: «El hecho de que los cementerios pasen a estar intramuros a extramuros de las ciudades, significa no solo una variación en la ubicación de un edificio, sino que debió suponer la incorporación de ideas nuevas que debieron debatirse contra intereses circunstanciales por un lado y de otra parte vencer la inercia para lograr lo que consideraban mejor para mantener la salud de la población, realizándose las inhumaciones fuera de las ciudades» (PERAL PACHECO, op. cit., p. 269).

${ }^{11}$ Así, dice Pingarrón-Esaín acerca de la construcción del cementerio de Valencia que, a semejanza de lo ocurrido en otras capitales hispanas, «deviene de la mentalidad ilustrada dieciochesca, que con sus criterios avanzados y científicos pretendía, unificando los enterramientos en una gran camposanto alejado del casco urbano, evitar los inconvenientes sanitarios de las inhumaciones» (PINGARRÓN-ESAÍN, F. (2008). «El patio de columnas y la cruz monumental del cementerio general de Valencia y otros datos durante el siglo XIX». Ars Longa, n 17 , pp. 117-135, p. 117). En modo parecido se expresa Brel Cachón: «Los cementerios se construyen durante la segunda mitad del siglo XVIII y el XIX, según las ideas urbanísticas del momento y el racionalismo y la higiene son los principios que rigen su construcción» (op. cit., p. 183).

${ }^{12}$ GRANJEL, M. CARRERAS PANCHÓN, A. (2004) «Extremadura y el debate sobre la creación de cementerios: un problema de salud pública en la Ilustración». Norba. Revista 
De ahí que en su iniciativa Miguel Domingo, y luego Antillón, en los textos que más por lo extenso examinaremos a continuación, resalten dicha particularidad como refuerzo en su propósito de enterrar en despoblado. En lo concerniente a Domingo, hasta por dos veces encontramos una apelación a tal facultad de discernimiento: «Abramos alguna vez los ojos, amados compatriotas, escuchemos las voces de la razón», «Todo hombre de razón se hallará convencido de la necesidad y urgencia de que se lleve a efecto esta medida ${ }^{13} \gg$. Por su parte, Antillón reprenderá «la bárbara e irracional costumbre, introducida generalmente de enterrarse los cadáveres en el recinto del templo y bajo los pies del pueblo, allí reunido para orar a Dios ${ }^{14} \gg$.

Abundando en el tema, no resultará tampoco ocioso recordar que una de las figuras más emblemáticas de la Ilustración española, D. Gaspar de Jovellanos, había sido un ferviente defensor de aquella misma causa, y por medio de su propio testimonio sabemos que renunció al derecho que poseía de ser enterrado en una capilla propiedad de su familia, puesto que como él mismo refiere: «fue siempre mi deseo el que mis huesos reposasen en el cementerio de la iglesia parroquial de Gijón, en la cual fui bautizado [...]», a la vez que se encarga de dejar constancia del especial empeño que puso en sacar adelante el camposanto gijonés: «si yo falleciere en Gijón, mando que se me dé sepultura en el nuevo cementerio, a cuya construcción he concurrido con mis continuos ruegos y solicitud ${ }^{15}$ ».

Ha de mencionarse a este mismo propósito que la personalidad de Jovellanos en modo alguno había causado indiferencia en el grupo liberal mallorquín, sino que, antes al contrario, había suscitado una honda huella en muchos de sus componentes ${ }^{16}$, especialmente por la lucha de aquel ideal que remarca Antillón,

de Historia, vol. 17, pp. 69-91, p.78.

${ }^{13}$ Ambas expresiones aparecen en la Aurora Patriótica Mallorquina de 18 de julio de 1812, nº 34, pp. 141 y 143 , respectivamente.

${ }^{14}$ Aurora Patriótica de 15 de setiembre de 1812, n 93, p. 386. Respecto del artículo publicado aquí por Isidoro de Antillón (más que probable autor del mismo), como del anteriormente señalado de Miguel Domingo, volveremos más adelante con bastante mayor detenimiento.

${ }^{15}$ JOVELLANOS, G. P. de. (1956). «Testamentos y memorias testamentarias (1795-1810)». En MIGUEL ARTOLA (ed.). Obras publicadas e inéditas de D. Gaspar Melchor de Jovellanos. Madrid: Biblioteca de Autores Españoles, no 87, tomo V, pp. 276a. ÁLVAREZ-VALDÉS Y VALDÉS, M. alude a esta cuestión en Jovellanos: vida y pensamiento (2012). Oviedo: Ediciones Nobel, p. 376.

${ }^{16}$ Así lo muestra el texto siguiente, que informa de la edición de una obra de Jovellanos, fruto de una pluralidad de voluntades: "Las memorias que ahora publica el celo de algunos apasionados de este esclarecido personaje, honor de la toga, dechado de hombres públicos y mártir de la virtud y de la libertad [...]» («Advertencia del editor», posiblemente redactada por Antillón, en JOVELLANOS, G. P. de. (1813). Memorias históricas sobre 
cuando se refiere a él: «un nombre precioso que añadir al martirologio de la libertad española ${ }^{17} \gg$. Consecuentemente, la Aurora Patriótica Mallorquina no escatimará esfuerzos por defender su recuerdo: «la respetable memoria del ciudadano más virtuoso e ilustrado, cuya muerte debiera llorar la nación ${ }^{18} »$, ni ahorrará tampoco palabras en su elogio ${ }^{19}$.

Sin dejar de la mano esta gaceta, ha de significarse la circunstancia de que la Aurora Patriótica Mallorquina, el periódico que aglutinaba a los liberales de Mallorca, solía prestar mucha atención a los asuntos concernientes a la salubridad pública, Junta de Sanidad, gestión de hospitales, etc., y se hallaba pronta siempre en requerir al Ayuntamiento en cuanto a la adopción de medidas que mejoraran la limpieza y saneamiento de la ciudad ${ }^{20}$. Por otra parte, no podemos olvidarnos de que uno de sus fundadores, Isidoro de Antillón, notable geógrafo, y persona de manifiesto interés por otras materias científicas, tales cuales la Astronomía, las Matemáticas, etc., participó durante su etapa de diputado en diversas comisiones del Congreso relativas a la salud, en prueba creemos que evidente de esa su permanente inquietud ${ }^{21}$.

En cuanto al otro pilar sobre el que se cimentó la Aurora, su editor e impresor, Miguel Domingo ${ }^{22}$, ha de reseñarse que tampoco él se quedó corto en tales menesteres. Al revés, pues su talante renovador, unido a una energía arrolladora y al entusiasmo admirable que ponía en todas las empresas en las que participaba,

el castillo de Bellver en la isla de Mallorca. Obra póstuma de Don - . Palma: Imprenta de Miguel Domingo, h.s.n.).

${ }^{17}$ ANTILLÓN Y MARZO, I. de. (1812). Noticias históricas de D. Gaspar Melchor de Jovellanos [...]. Palma: Miguel Domingo, p. I.

${ }^{18}$ Aurora Patriótica Mallorquina de 25 de octubre de 1812, nº 8, «Dos palabras en desagravio del señor Jovellanos, ultrajado vilmente por el diarista de la tarde», sin firma, p. 89.

${ }^{19}$ Como, por ejemplo, en su $\mathrm{n}^{\circ} 69$, de 13 de junio de $1813, \mathrm{n}^{\circ} 69$, en el que se anuncia la puesta a la venta de las «Memorias históricas sobre el castillo de Bellver en la isla de Mallorca: «El nombre solo del autor es la mayor recomendación que puede tener cualquiera de sus producciones literarias. Su pluma ha enriquecido a la nación con una porción considerable de escritos» (p. 106).

${ }^{20}$ Puede consultarse al efecto: RODRÍGUEZ MORÍN, F. (2014). «La salud pública a través de la prensa liberal mallorquina en los tiempos de las Cortes de Cádiz». Memòries de la Reial Acadèmia Mallorquina d'Estudis Genealògics, Heràldics i Històrics, nº 24, pp. 107-126.

${ }^{21}$ Con razón puede aseverar León Esteban que «si algo es Antillón, es un hombre de ciencia por vocación, acción y pasión permanente» (ANTILLÓN Y MARZO, I. (1994). En Esteban, L. (ed.). Noticias históricas de don Gaspar Melchor de Jovellanos. Valencia: Universidad de Valencia, p. 27).

${ }^{22}$ Sobre el preponderante papel de Domingo en la Aurora, puede consultarse: RODRÍGUEZ MORÍN, F. (2013). «Miguel Domingo, editor de la Aurora Patriótica Mallorquina (1812-1813)». El Argonauta Español, nº 10, livraison juin, http://argonauta.revues.org 
dejó también, como más adelante veremos, su particular huella en este asunto, de tanta trascendencia para el conjunto social. Baste decir, para dejar breve constancia ahora respecto de su perenne labor innovadora, que la misma se extendió a una generalidad de materias, desde la modernización en las técnicas de su oficio de impresor ${ }^{23}$, hasta la centralización en su librería palmesana (en la Plaza de Cort, frente a la cárcel) de la recogida de firmas para felicitar a las Cortes por la supresión del Santo Oficio, o que empleó ese su mismo local de comercio, tan denostado por sus enemigos ideológicos, para cumplir con la función social de atender a los más desfavorecidos ${ }^{24}$.

Ese amor por los avances hizo de él un escrupuloso admirador de la ciencia y de sus descubrimientos. Por eso se encargará de dedicar tres páginas enteras de su periódico a un «Anuncio» cantando las excelencias del ácido cítrico cristalizado: «con una onza de este ácido cítrico cristalizado pueden hacerse treinta y cinco vasos por lo menos de cítrico de limonada regular de cuarto, o de libra [...]». Además, como buen negociante que era, aprovechará para venderlo en su establecimiento: «Se hallará de venta en frasquillos [...] en la librería de Miguel Domingo ${ }^{25}$ ».

Tal afición es comprobable asimismo con la acogida en la Aurora de noticias relacionadas con el conocimiento científico, caso de su $\mathrm{n}^{\circ} 14$ ( $2^{\mathrm{a}}$ época), de 15 de noviembre de 1812, en donde tras el epígrafe, carente de firma, «Establecimiento de una escuela de Botánica», se ocupaba casi por entero la página 176 en informar sobre el hecho de que Francisco Gil Rodríguez iba a ser el primer profesor en dar clase de Botánica en Mallorca, así como de diversos aspectos relativos a sus méritos, y al precio, o lugar en que impartiría sus lecciones.

Por todo ello no nos debe extrañar que, al mes de nacer la Aurora Patriótica Mallorquina, cuando el sofocante calor del verano, en el cénit del mes de julio, acentuaba el olor a putrefacción de los cadáveres, sacara a la luz Miguel Domin-

\footnotetext{
${ }^{23}$ Así se lo reconoce Miguel Oliver, cuando afirma que con sus «trabajos de escogida perfección [...], contribuyó no poco a realzar el gusto de las imprentas mallorquinas entonces completamente descuidadas y semibárbaras, sin esmero ni corrección ni elegancia de ninguna especie» (OLIVER, M. de los S. (1901). Mallorca durante la primera revolución (1808-1814). Palma: Imprenta de Amengual y Muntaner, p. 506).

${ }^{24}$ Aurora Patriótica de 12 de setiembre de 1812, n 90, en la sección «Avisos» se apela a la generosidad de los palmesanos para socorrer a los «pobrecitos soldados estropeados e inútiles, que se hallan en esta plaza», pues alega que estando a las puertas del invierno, la mayoría se encuentran desnudos, facilitándose el establecimiento comercial de Miguel Domingo como punto de recaudación del dinero para su auxilio: «El que quiera socorrer esta indigencia podrá hacerlo, con la limosna que fuere de su agrado, en la librería de Miguel Domingo frente la cárcel» (p. 376).
}

${ }^{25}$ Aurora Patriótica de 17 de julio de 1812, nº 33, pp. 138-140, p. 140. 
go un artículo, en el que consecuente con los dictámenes de la ciencia médica, se pronunciara de forma contundente contra la costumbre de enterrar en las iglesias.

Así ocurrió que el 18 de julio de 1812, en su no 34, publicó la Aurora Patriótica, abarcando tres de sus cuatro páginas (141-143), el artículo titulado «Salud pública». Aunque sin firma que nos identifique la autoría, parece que no hay mayores dudas en asignársela a Miguel Domingo, a cuenta de unas palabras suyas estampadas el 28 de setiembre de 1812, en el n ${ }^{\circ} 106$ de su periódico, donde —bajo la rúbrica «Al imparcial del diario de Palma de 26 de setiembre el editor de la Aurora» — signado, ahora sí, por «El editor de la Aurora», comenzaba agradeciendo al aludido comentarista del Diario de Palma el calor de su compañía en esta cruzada: «gracias a Dios que no lucho solo contra los abusos, y que una pluma tan juiciosa como la de vd. se presenta en la palestra para atacar conmigo el de enterrar en las iglesias y poblaciones» (p. 439).

\section{LA NORMATIVA LEGAL IMPERANTE}

Comenzaba Domingo aquel su primer alegato en la Aurora a favor de los cementerios haciendo hincapié en que la legislación estaba de su parte: «Debe decirse en honor a la verdad, que nuestro gobierno ha expedido diferentes órdenes dirigidas a establecer los cementerios fuera de las poblaciones» (p. 141). Tal aserto era totalmente cierto, y se remontaban las providencias de la autoridad en ese sentido (bien que sin prisa ninguna) al año 1787, a raíz del famoso incidente acaecido en la localidad guipuzcoana de Pasajes en 1781, que el profesor de cirugía Joaquín de Villalba, a comienzos del siglo XIX, relataba así:

por el mes de Marzo de este año [1781] se adoleció de una epidemia, de la cual solo en el expresado mes y en los seis anteriores enfermaron ciento y veinte personas, de las que fallecieron ochenta y tres. El origen de este contagio se atribuye al fetor intolerable que exhalaba la parroquia de aquel pueblo por los muchos cadáveres allí sepultados; por manera, que entre otras providencias dirigidas a atajar el contagio, fueron precisas las de cerrar, destejar y ventilar la iglesia, hacer los entierros solo en el cementerio $\mathrm{y}$ atrio y trasladar enteramente la parroquia a otra parte ${ }^{26}$.

\footnotetext{
${ }^{26}$ VILLALBA, J. de. (1803). Epidemiología española, o historia cronológica de las pestes, contagios, epidemias y epizootias que han acaecido en España desde la venida de los cartagineses hasta el año 1801 [...]. Madrid: Villalpando, t. II, p. 146. Este suceso famoso es consignado, entre otros varios autores, por Luis Redonet (pp. 30-31), quien previamente nos había dado unas pinceladas del mal aparejado procedimiento que se llevaba a cabo en aquellos tiempos: «El abuso de los enterramientos, sin limitaciones ni precauciones sanitarias de ninguna clase, en iglesias muy concurridas y mal ventiladas: la saturación en ellas de cuerpos putrefactos mal cubiertos con una ligera capa de tierra o bajo losas o pavimentos removidos y mal ajustados, acabaron por motivar hedores insoportables y dañosos para la salud pública, muchas infecciones y sonadas epidemias de
} 
Como consecuencia de tan lamentable episodio, Carlos III en su cédula de 3 de abril de 1787, sin querer omitir su conmoción: «se enterneció mi corazón a vista de aquel desgraciado suceso», ordenó el retorno a la antigua disciplina, ya contemplada en las Partidas de Alfonso X, de no dar sepultura en las iglesias, salvo en los supuestos en aquellas atendidos ${ }^{27}$. Pero el disparo se quedó, sin embargo, en poco más que en una salva ${ }^{28}$.

Nueve años más tarde, siendo rey su hijo Carlos IV, se promulgará otro precepto relativo a este tema, más acorde ahora con la realidad de las cosas o, lo que es lo mismo, más consecuente con las dificultades de financiar los nuevos camposantos y con el impedimento, no menor, de encauzar la mentalidad de las gentes para su utilización. En dicha disposición, después de reconocerse los perjuicios de la praxis habitual: «no habiendo cosa que más se oponga a la salud de los hombres que enterrar los cadáveres dentro de los Templos, en sus bóvedas e inmediaciones», se contempla una especie de parche o de remedo de solución para ir tirando: «hasta que llegue el feliz momento de la erección de cementerios rurales [...], será conveniente, que cuide el Presidente y la Junta de Gobierno de Medicina, que los cadáveres se sepulten con la profundidad competente ${ }^{29} \gg$.

mortales consecuencias» (REDONET, L. (1942). Enterramientos y cementerios. Madrid: Viuda de Estanislao Maestre, p. 29).

${ }_{27}$ «Que se observen las disposiciones Canónicas, de que soy Protector, para el restablecimiento de la disciplina de la Iglesia en el uso y construcción de Cementerios, según lo mandado en el Ritual Romano, y en la ley once, título trece, partida primera; cuya regla y excepciones quiero se sigan por ahora» (Real Cédula de S. M. y señores del Consejo, en que por punto general se manda restablecer el uso de Cementerios ventilados [...]; citamos por el folleto impreso por Pedro Marín en Madrid, en 1787, h. s. n.). Vovelle considera esta medida un reflejo de las disposiciones adoptadas en el mismo sentido en Francia en 1776 (Vovelle, M. (1983). La mort et l'Occident, de 1300 á nos jours. París: Gallimard, p. 425).

${ }^{28}$ A juicio de José Luis Santonja, el fracaso en la puesta en marcha de los cementerios constituyó una excepción en la, por otra parte, dinámica política en materia de higiene fomentada en España durante el Siglo Ilustrado: «La perspectiva del Estado se planteó desde el punto de vista higiénico. Si durante todo el siglo XVIII se sucedieron políticas de prevención para desterrar el riesgo de epidemias, con el control del tráfico portuario, la ejecución de planes generales del alcantarillado y la retirada de desperdicios de las vías públicas, el enterramiento en el interior de las poblaciones continuaba constituyendo un evidente riesgo para la salud pública» (SANTONJA, J. L. (1998-1999). «La construcción de cementerios extramuros: un aspecto de la lucha contra la mortalidad en el Antiguo Régimen». Revista de Historia Moderna, nº 17, pp. 33-44, pp. 33-34).

${ }^{29}$ Real Cédula de 15 de noviembre de 1796, «Reglas sobre la policía de la salud pública, que se han de observar por la suprema Junta de gobierno de Medicina», párrafo segundo, en la Novísima recopilación de las leyes de España. Mandada formar por el Señor Don Carlos IV. (1976). Madrid: B. O. E., tomo III, título XL, ley V, p. 725b. 
Todavía con el gobierno de Godoy, se comenzaron a asentar en 1804 las bases de un plan para la construcción de cementerios municipales, dictando una serie de normas en tal sentido, tal y como apunta Roura i Aulinas, aunque tampoco se consiguió con ello agilizar gran cosa su entrada en funcionamiento, pues «la lentitud de la seva posta en pràctica era alhora causa i conseqüència del manteniment del costum d'enterrar a les esglésiès $i$ en els seus cementiris ${ }^{30} \%$. Posteriormente, en la orden sobre cementerios de 23 de julio de 1806, dirigida al intendente de Mallorca por el palmesano Miguel Cayetano Soler, secretario del Despacho de Hacienda, se manejaba ya, según transcribe Llabrés ${ }^{31}$, una cantidad global como presupuesto para edificar los cuarenta cementerios que se habían designado para la isla de Mallorca, ascendiendo el conjunto a la suma de 877.025 reales, que el intendente debería detraer de los caudales de la Real Hacienda y depositar en la tesorería del ejército.

Pero nuevas causas retrasaron una vez más los trabajos: «A partir d'aquest moment, la causa principal de la lentitud en la realització de les obres, cal cercalla en la manca de fons. En bona part es sufragaven amb donatius de diversa índole ${ }^{32} \gg$. Por si fuera poco, en 1808, el inicio de la guerra con Napoleón supuso prácticamente la paralización del proyecto ${ }^{33}$.

${ }^{30}$ ROURA I AULINAS, L. (1985). L'Antic Règim a Mallorca. Abast de la commoció dels anys 1808-1814. Barcelona: Conselleria d'Educació i Cultura de les Illes Balears, p. 75. Por su parte, Salas Vives señala que la primera circular por él localizada sobre la construcción de cementerios en Mallorca data de junio de 1804 (Actas Municipales de Pollen$s a$, Órdenes, 1681): «Aquesta circular va anar seguida d'un reglament per a la construcció de cementeris, en el qual queden patents els motius higienistes (i concretament infeccionistes) que n'impulsaven la creació» (SALAS VIVES, P. (2002). «Les obres públiques a Mallorca durant el segle XIX. Consideracions sobre l'acció de l'administració pública a 1'època contemporània». Mayurqa, $\mathrm{n}^{\mathrm{o}}$ 28, pp. 53-74, p. 66).

${ }^{31}$ LLABRÉS Y BERNAL, J. (1958). Noticias y relaciones históricas de Mallorca. Siglo XIX. Palma de Mallorca: Sociedad Arqueológica Luliana, t. I (1801-1820), pp. 109-110.

${ }^{32}$ ROURA, op. cit., p. 75.

${ }^{33}$ De todas formas, y en clara muestra de que el dinero no siempre constituía el impedimento principal para sacar adelante la reforma en los enterramientos, sino más bien la falta de una clara voluntad de sustituir un rito por otro, transcribimos a continuación lo acontecido en el municipio de Felanitx: «Es el caso: que el nuevo ayuntamiento constitucional queriendo llevar a efecto la orden sobre formación de sementerios [sic], y hallándose sin fondo alguno disponible, determinó excitar la beneficencia de sus conciudadanos, enviando sus carros y criados a conducir materiales para la recomposición del camino y construcción del cementerio; en efecto dispertó [sic] tal emulación, que a porfía concurrieron a aquella obra pública de modo que en tres días y medio quedó cerrado el cementerio por una pared de 11 pies de alto, y concluido el camino con solo el gasto de 79 libras, siendo así que no se hace una obra semejante con 10[000] rs. de vellón» (escrito de Pedro Galera 
No será hasta bien cumplido el 1809 cuando la Administración transmita de forma imperiosa la prohibición de continuar como hasta el momento. La Junta Central se manifiesta ahora de forma terminante y categórica:

que el Consejo reitere las ordenes más expresas, enérgicas y terminantes, para que sin la menor demora se establezcan [...] en todo el Reino cementerios, sin que se permita absolutamente enterrarse en poblado a nadie, comprendiéndose todos los Cuerpos y Comunidades religiosas de uno y otro sexo, por privilegiados que sean ${ }^{34}$.

Y es justamente en este período, en julio de 1812, tal vez porque no adelantaban las operaciones al ritmo que debieran, cuando plantea la Aurora el asunto a la opinión pública; como si con ello pretendiese darle el empuje definitivo. Y poniendo el ejemplo de Cádiz y de otras ciudades de la Península, en las cuales, según apunta, hacía ya tiempo que no se permitía a nadie sepultar dentro de la población, se pregunta: «¿Por qué no se ha de hacer lo mismo en esta capital, donde ya se han gastado cuantiosas sumas en la construcción de un cementerio? Poco falta para concluirle $[\ldots]^{35} \gg$.

\section{LA DENUNCIA DE MIGUEL DOMINGO, O LOS RIESGOS FÍSICOS DE AFERRARSE A MÉTODOS ANTIGUOS}

Ha de resaltarse que el editor de la Aurora Patriótica parecía bien informado respecto de los peligros físicos que el enterramiento en los templos podía traer para la salud, y así refiere que, «los escritos de varios médicos celebres y de otros autores instruidos demuestran hasta la evidencia, cuan perjudiciales son a la existencia de los vivos los miasmas que exhalan los cuerpos muertos» (p. 141). Circunstancia esta, según expresa, de sobra acreditada por la experiencia: «Se reseñan tristes ejemplos de desgracias, que ha producido la práctica de enterrar en las iglesias» (pp. 141-142). Por lo tanto, también en este punto, al igual que en el terreno legal, pisaba Miguel Domingo sobre seguro, y podía doblegar las suspicacias de los que sospechaban que la nueva costumbre de enterrar en despoblado no era sino una moda, otra más, importada de Francia por aquellos «filósofos» liberales que pretendían acabar con las tradiciones hispanas. Tal vez por eso, curándose en salud (valga la expresión), el anteriormente mencionado doctor Villalba se había encargado de aderezar hábilmente los dictámenes de la

dirigido al redactor del periódico, en una hoja, sin numerar, tras el Diario de Mallorca de 15 de febrero de $\left.1814, n^{\circ} 46\right)$.

${ }^{34}$ Archivo Histórico Nacional, Consejos, 12006, exp. 15. Resolución de la Junta Central Suprema, despachada en Sevilla el 27 de setiembre de 1809.

${ }^{35}$ Aurora Patriótica de 18 de julio de 1812, cit., p. 143. 
Medicina con las bendiciones teológicas: «Los celosos académicos con la autoridad de los sagrados Cánones, de varios Concilios, \&c. prueban concluyentemente lo perjudicial que es el uso de las sepulturas dentro de las iglesias y pueblos ${ }^{36} »$.

De modo semejante, Miguel Domingo, se cuida también de incluir en su escrito argumentos de índole religiosa, alegando que «de ninguna manera es conveniente ni decoroso, que los templos, donde se reúnen los fieles diariamente, y donde se venera la majestad del mismo Dios, estén infestados con el mal olor, que despide por necesidad un cuerpo putrefacto» (p. 142); a la par que expone su opinión acerca de los motivos de algunos para oponerse u obstaculizar los enterramientos en los cementerios, y que lejos de hallar asiento en la devoción o en una mayor utilidad espiritual, se sustentaban en «una vanidad ridícula, contra la cual es necesario que prevalezcan en adelante los gritos de la humanidad y las verdaderas máximas del cristianismo» (p. 143).

Reforzaba, además, Domingo esta serie de razonamientos con otros de tipo histórico, y remontándose a las leyes instauradas en la antigüedad por griegos y romanos, manifiesta que habían sido escrupulosamente respetadas por los cristianos de los primeros siglos (p. 142). Por otra parte, no se priva tampoco de destilar una nota de añoranza hacia los progresos alcanzados por otros países europeos en eso de inhumar a los muertos en las iglesias, «que la ilustración va desterrando de todas las naciones cultas menos de la nuestra» (p. 141).

Por otra parte, jugaba el editor de la Aurora Patriótica, en este su propósito, carta tan favorable cual era la señalada por Miguel Oliver cuando nos descubre cierta singularidad de la idiosincrasia mallorquina: «el pánico indescriptible que ha causado por regla general en Mallorca el anuncio de una epidemia, aun incierta y lejana, hasta el extremo de ser el único asunto capaz de mover radical y poderosamente la opinión pública en este país ${ }^{37} \gg$.

Respecto de este mismo asunto, opondrá el propio Oliver, a ese sentir de «la gran masa, dominada por el terror pánico de las epidemias» (p. 263), el más ponderado de las gentes ilustradas. Quizá por tal motivo, Miguel Domingo, que ni pertenecía a esa «gran masa», y ni tan siquiera era mallorquín, no sintiera empacho alguno en prevalerse de tal peculiaridad de los isleños, y de aprovechar los miedos de aquellos en la iniciativa por él promovida ${ }^{38}$. A este efecto,

\footnotetext{
${ }^{36}$ VILLALBA, op. cit., p. 146.

${ }^{37}$ OLIVER, op. cit., p. 251.

${ }^{38}$ De nuevo Miguel Oliver será quien, aun indirectamente, nos confirme lo efectivo que podía resultar dicho recurso: «Ni las lecciones de la experiencia ni el influjo del progreso científico habían bastado a desterrar la costumbre de los enterramientos dentro de las iglesias. La real cédula de Carlos III, de 3 de abril de 1787, había quedado sin cumplir; y
} 
no ha de olvidarse que durante los años 1811 y 1812 pervivió, proveniente de América, un foco de fiebre amarilla, introducido por el puerto de Cádiz, que se extendió por todo el Levante español. Por lo cual, con la amenaza de la enfermedad frente a su costa, el ánimo de los habitantes baleares se hallaría más que sensible hacia toda posibilidad de contagio en el tiempo en que publicó Domingo su denuncia.

En un «Articulo comunicado», firmado por «La Razón», y alumbrado en la Aurora Patriótica el 11 de setiembre de $1812, \mathrm{n}^{\circ} 89$, se reconoce que, gracias a su situación insular, Mallorca se había librado «del contagioso mal, que se ha padecido estos años pasados y hoy día se padece en nuestra península» (p. 370), y concluye con una nueva alusión a los peligros que, no muy lejos, acechan, esto es al «riesgo de que se introduzca en esta isla la epidemia, de la que estamos tan amenazados» (p. 371), todo ello con el afán de perfeccionar el sistema de cuarentena impuesto a los buques que llegaban a aquellas $\operatorname{tierras}^{39}$.

Son puntos estos con los que, desde luego, comulgaba plenamente la línea editorial de la Aurora Patriótica, la cual, a través de una «Nota de la Aurora», solventando toda duda, se pronuncia así: «Ningún rigor es excesivo cuando se trata de hacer observar puntualmente las precauciones que se han juzgado precisas para evitar la introducción de una epidemia ${ }^{40} \gg$.

La razón de fijarnos en esta cuestión del terror a los contagios, especialmente entre la población mallorquina, nos sirve, además de para pergeñar el contexto en el que fue alumbrada la denuncia de Miguel Domingo, para subrayar que pudo ser precisamente aquella una de las causas que coadyuvó a su publicación,

fue preciso que los terribles contagios de los primeros años de este siglo, preparasen de nuevo el terreno e inclinasen el ánimo a favor de la reforma» (op. cit., p. 144).

39 La Aurora del 14 de setiembre, $\mathrm{n}^{\circ}$ 92, torna a la carga sobre el mismo asunto en un «Artículo comunicado», quizá de la misma mano que el del día 11, firmado ahora por «La verdad», pp. 382384. Por su parte, la Aurora de 5 de noviembre de 1812, nº 11 (2 época), pp. 135-136, estampa un escrito titulado «Sanidad» ( $\sin$ firma), en el que alerta de que en Alicante habían muerto dos personas con los síntomas de fiebre amarilla; y, tras exponer el hecho de resultar esta «una desgracia, de que hasta ahora hemos podido escaparnos por un milagro del cielo» (p. 135), termina con una seria advertencia: «En esta materia nunca es superflua la escrupulosidad más rigurosa» (p. 136).

${ }^{40}$ Aurora Patriótica de 6 de setiembre de 1812, no 94, p. 392. Todavía un año después, el anónimo «X. D.», en la Aurora Patriótica del 29 de julio de 1813, nº 82, iniciaba sus reflexiones de la manera siguiente a continuación del rótulo «Salud pública»: «Cuando esta peligra, ¿qué objeto más digno puede proponerse el que ama a su patria, que el de proponer al gobierno lo que crea útil?» (p. 277). Y a tal fin destina su escrito, proponiendo fórmulas que mejoren la vigilancia de las embarcaciones que arriban a Mallorca, a cuenta todo del miedo al «contagio del continente» por la reseñada fiebre amarilla. 
al tener menos probabilidades de que sus tesis cayeran en saco roto que si fueran plasmadas en un entorno carente de riesgos graves para la salud ${ }^{41}$.

\section{REPERCUSIÓN EN LA OPINIÓN PÚBLICA DE LAS TESIS DE MIGUEL DOMINGO}

Quizá hubiera quedado aquel del editor de la Aurora Patriótica como único testimonio en la prensa periódica mallorquina que nos diera cuenta del problema de enterrar en las iglesias, si no fuera por un artículo que se publicó en el n ${ }^{\circ} 93$ de la misma Aurora, el 15 de setiembre de 1812, y que sus adversarios ideológicos lo juzgaron - parece que con buen tino- procedente de la bien templada pluma de Isidoro de Antillón, destinado entonces en Mahón ${ }^{42}$.

Apareció este escrito, fechado el día 3 de setiembre, carente de título, ocupando las páginas 385-387 del periódico que se ha dicho; e iba dirigido, según se pone de manifiesto en su primera línea, al editor de la Aurora, a quien insta además a no desfallecer en su campaña: «vd. siga intrépido su carrera» (p. 386). Suscribía en él enteramente el magistrado aragonés la fundamentación de su amigo y correligionario Miguel Domingo acerca del controvertido asunto de los cementerios: «Uno de los artículos más útiles que vd. insertó en su periódico, fue sobre los cementerios, insinuando los perjuicios que la salud publica recibía de la bárbara e irracional costumbre, introducida generalmente de enterrarse los cadáveres en el recinto del templo y bajo los pies del pueblo, allí reunido para orar a Dios» (p. 386).

Tras tildarla de «práctica abusiva», lanza el articulista contra los defensores de tal costumbre el arsenal de la ciencia moderna, y así explica que ha sido

${ }^{41}$ Sobre este preciso extremo, comenta José Javier Viñes que las medidas sanitarias a lo largo del siglo XIX y buena parte del XX no tenían de ningún modo un carácter estable: «sino que son adoptadas por el Estado [...] cuando la mortalidad epidémica es asoladora; cuando hay que sacar a los muertos de las ciudades y poblados, lo que obliga a recuperar y reactivar la legislación sobre cementerios; se prohíbe en las iglesias "tocar a muerto", para que no se alarme la población y los funerales "de cuerpo presente", realizándose los enterramientos durante la noche; en tanto que en los periodos interepidémicos, el Gobierno, los delegados gubernativos y los alcaldes se olvidan de la salubridad» (VIÑES, J. J. (2006). La sanidad española en el siglo XIX a través de la Junta Provincial de Sanidad de Navarra (18701902). Pamplona: Fondo de Publicaciones del Gobierno de Navarra, p. 26).

${ }^{42}$ Así nos lo da a entender el anónimo autor del «Artículo comunicado», publicado por el Semanario Cristiano de 22 de octubre de 1812, $\mathrm{n}^{\circ}$ 13, p. 147: «Luego que a la luz de un candil (tan oscura es la Aurora) leí el núm. 93, luego dije a mi capote: este escribe desde Menorca, y a tiro de ballesta se conoce su autor. Si V. me pregunta, ¿en que lo conocí? Respondo, que en aquello de fanatismo, ignorancia, superstición, sublimes máximas del Evangelio, religión divina, libros santos, sistema de caridad, \&c. \&c. con que se suele atestar a sus producciones, y son cláusulas de su estilo». 
«combatida últimamente por todos los argumentos de la medicina, de la química, de la buena policía urbana [...]». Y se encrespa al recordar cómo el protagonismo de Miguel Domingo en este tema le había valido la condena, incluso desde el púlpito, de algún que otro fraile; señalando entre estos al P. Traggia, a quien parece «dedicar», además, este su comunicado, pues lo deja signado como «El amigo de la verdad (no por antífrasis)», en clara alusión a la publicación periódica del mentado carmelita zaragozano, frente a quien - junto con su esposa, Josefa Piles Rubín de Celis («que presume de filósofa $\left.{ }^{43} »\right)$ - mantenía Antillón pública enemistad.

A modo de colofón a su envío, aportaba este nuevo «amigo de la verdad» (pp. 387-388) la traducción castellana de un fragmento, correspondiente a las páginas 224-227, del ya citado libro de Grasset de Saint Sauveur, Voyage dans les iles Baléares et Pithiuses, de cuyas reflexiones entresacamos el siguiente párrafo, destinado, sin duda, a provocar el miedo con fines pedagógicos por ambos autores, el francés y el español; a ello posiblemente se unía en el segundo, en Antillón, la intención de ilustrar gráficamente la patética imagen que podíamos estar dando en Europa:

Los parientes, los amigos que vienen a regar con sus lágrimas la losa que los cubre, no sacan de su piedad otra cosa muchas veces, que el germen de una enfermedad, que bien pronto los precipita en la misma huesa. ¿Cuántos ejemplares de muertes repentinas no han ocurrido, al abrirse estas simas pestilenciales? Y sin embargo la experiencia de peligro tan real no ha bastado para destruir una confianza ridícula... (p. 387).

El tratamiento de este tema en la Aurora acabó por tener respuesta entre sus lectores. Y así su n ${ }^{\circ}$ 96, de 18 de setiembre de 1812, insertaba un «Articulo comunicado», firmado en Palma el 15 de setiembre (esto es, el mismo día en el que se publicó el anterior) por dos suscriptores: «S. y S. ${ }^{44} »$, con el ánimo de formular una pública denuncia. Tal misiva comenzaba así: «Sr. editor de la Auro-

\footnotetext{
${ }^{43}$ SANTO TOMÁS, fray Manuel de. (Manuel Traggia Uribarri), Cuadro político y moral de España en los años 1810 y 1811 (fechado en Malta, el 16 de julio de 1813), citamos por J. NAVARRO CABANES (1921). El padre Traggia. Memorias autógrafas inéditas [...]. Valencia: Diario de Valencia, p. 28. Tal vez aprovecha de Antillón la parte final del seudónimo aquí empleado por aquel, cuando clama Traggia «contra los errores introducidos en este siglo, llamado ilustrado por antífrasis» (ibídem, p. 25).

${ }^{44}$ La lista de suscriptores facilitada en el último número (127) de la Aurora Patriótica Mallorquina, publicado el 30 de diciembre de 1813, incluye dos nombres cuya primera letra del apellido comienza por esa misma «S» que la de los signatarios del artículo: Bartolomé Socías y Dezi (escribano) y Bartolomé Socías y Gomila; dicha filiación, además, sugiere parentesco y, por ende, mayor facilidad en dar conjuntamente su parecer al periódico de Domingo. Aunque desde luego no podemos, con tan magro bagaje argumental, ni tan siquiera sugerir la hipótesis de su autoría, aparte de que la mencionada relación da cabida a otros apellidos con dicha inicial.
} 
ra: dos apasionados de vd. y suscriptores antiguos de su periódico esperan de su bondad se servirá insertar en él estas cuatro palabritas, relativas al trozo del Viaje a las islas Baleares» (p. 397).

Referían allí los comunicantes que el lugar a que se aludía en una parte de dicha transcripción, en el exterior del muro de Ciudadela, se llamaba vulgarmente Campo Santo, el cual fue comprado durante la época de la peste por el Ayuntamiento con el fin de enterrar allí a las personas muertas por tal enfermedad, «evitando de este modo que los que sobrevivieron al soplo mortífero del contagio, fuesen tristes víctimas de los miasmas de los cuerpos muertos» (p. 397). Sin embargo, el indicado terreno, «que debiera haber sido mantenido por la caridad cristiana, y en donde deberían enterrarse hoy día los muertos; ha sido vendido en estos últimos años ¡quién lo creyera! por la mano benéfica del R. obispo de Menorca ${ }^{45} \gg$.

La repercusión del asunto entre la opinión pública hará que el debate salte de la Aurora a otros periódicos; fue ese el caso del Diario de Palma, que en su $\mathrm{n}^{\circ}$ 16, de 21 de setiembre de 1812, sacó un «Artículo comunicado», firmado en Palma el 20 de setiembre por «El Católico político», en el que, tras aludir a lo expuesto por «S. y S.» en la Aurora de 18 de setiembre, afirmaba que en 1810 el gobernador entonces de Menorca había hecho presente al obispo «la perjudicial e inhumana costumbre de enterrar en las iglesias, citándole las reales órdenes que prohibían este abuso» (p. 61). Y concluía el texto —además de con determinadas críticas a los frailes de Ciudadela- formulando unas manifestaciones en las que subyace aquel temor que Oliver juzgaba como inherente al carácter balear: «Es de advertir que en los templos de S. Francisco y el Carmen de Mahón se nota en las estaciones calorosas un vapor mefítico inaguantable, y ha sido una fortuna no haberse encendido el contagio» (p. 62).

Unos días más tarde, el mismo Diario de Palma, en su n 21, de 26 de setiembre de 1812, acogerá otro artículo de semejante tenor: «Se me desvaneció la nube, y todo cuanto se ha dicho y obrado después me ha confirmado más y más en la necesidad de observar la máxima de enterrar sino en cementerios campestres» (p. 83). Firmado en Palma el 15 de setiembre de 1812 por «El Imparcial ${ }^{46} »$, y dirigido al «Señor Editor de la Aurora», halló dicho escrito su origen en la

\footnotetext{
${ }^{45}$ En el Semanario Cristiano Político de 29 de octubre de 1812, n 14 , el titular de la diócesis menorquina, Pedro Juano, dará su propia versión de este suceso.

${ }^{46}$ Ignoramos si se trata de la misma persona que con idéntico alias publicó otro artículo en el mismo Diario de Palma, de 23 de noviembre de 1812, $\mathrm{n}^{\circ} 79$, en el que, haciendo honor a su nombre, procura mantener una postura ecléctica; y si bien reconoce que el proyecto de dar sepultura en los cementerios resultaba beneficioso para la sociedad, («Promuévase pues este en beneficio de la humanidad», p. 343), censuraba algunas críticas realizadas a diversos miembros del clero vertidas,
} 
inquietud de su autor a cuenta del mausoleo que se iba a construir en memoria del marqués de la Romana en la iglesia de Santo Domingo, de Palma de Mallorca. Dicho monumento, mandado erigir por las Cortes en señal de gratitud por los servicios prestados a la patria por tan célebre general, fue interpretado por muchos, entre ellos por nuestro anónimo comunicante, como un paso atrás en el proceso de concienciación que se estaba intentando promover por parte, especialmente, de los liberales, a causa del impacto que sin duda causaría entre las gentes: «Este ejemplar tendrá el influjo que es fácil prever; y será más poderoso que todos los discursos de los sabios, y que todas las órdenes del gobierno» (p. 83).

De esta forma el problema para los reformistas devenía en doble. Por un lado, porque a causa de eximir a un personaje tan importante de ser enterrado en descampado, y gozar, a la vez, de tanta repercusión el episodio, iba a resultar bastante más difícil hacer comprender al pueblo los beneficios de tal innovación: «Jamás se persuadirá el pueblo, a vista de esta excepción, ni de la solidez de los fundamentos de la prohibición, ni de la importancia de su observancia rigorosa» (p. 83). En segundo lugar, revestía también asunto de la mayor gravedad entender por qué las Cortes se habían despachado tan a despropósito y fuera de la lógica con esa disposición, que por lo mismo rayaba casi en lo despótico, puesto que como bien argüía «El Imparcial»: «las leyes que prohíben el enterrar en las iglesias, no se fundan en la distinción de clases, sino en las precauciones de sanidad y en el respeto debido a los lugares consagrados al culto», habida cuenta de que «sin duda que el cadáver del glorioso marqués de la Romana puede causar los mismos efectos de insalubridad que el de cualquiera otro» (p. 83).

Si típico del Siglo de las Luces había sido, según ya hemos mencionado, el entronizar a la Razón como guía rectora del ser humano, no menos importante se consideraba el alcance y trascendencia del ejemplo en la observación de las leyes, especialmente aquel que los grandes debían dar a los humildes, con el fin de preservarse por esta vía el buen ordenamiento social y evitar que un exceso de arbitrariedad o de injusticia pudiera conducir a disturbios, revueltas o, en definitiva, a la sinrazón. De ahí el trastorno que para aquellos antiguos ilustrados, remozados ahora en liberales, vendría a suponer la iniciativa de construir dentro de la iglesia un túmulo para depositar el cuerpo del marqués de la Romana. Por eso terminaba el articulista del Diario de Palma, escandalizado por la decisión del Congreso gaditano, demandando de su interlocutor unas palabras de sosiego: «Espero de Vmd. una respuesta que me restituya la tranquilidad» (p. 84).

Pretensión esta que obtuvo con suma prontitud la consiguiente respuesta, porque «El editor de la Aurora», apenas dos días después de haber sido plantea-

según hemos anotado, en la Aurora Patriótica, de 18 de setiembre de 1812, y en el Diario de Palma de 21 de setiembre, y que traían causa de esta misma materia de enterramientos en las iglesias. 
da la cuestión, dio a la luz su contestación en la Aurora de 28 de setiembre de $1812, \mathrm{n}^{\circ}$ 106, bajo el rubro «Al imparcial del diario de Palma de 26 de setiembre el editor de la Aurora». Se lamentaba en ella Miguel Domingo de que en Palma de Mallorca se hubiera comenzado a levantar un cementerio, y que, casi concluido, se hubieran quedado las obras paralizadas. Aunque, por lo que atañe a su contestación a «El Imparcial», no desmayaba en la esperanza de que el sepulcro al marqués de la Romana se llevara a cabo finalmente en el mencionado camposanto, puesto que las Cortes no habían señalado un lugar determinado en el cual ejecutarse; ello constituiría un audaz golpe de mano, y de paso un ejemplo impagable, por la repercusión nacional de tan famoso personaje, que con su cuerpo descansando en el cementerio abriría las puertas a que muchos otros, a su imitación, se convencieran de hacer lo mismo. De este modo, Miguel Domingo anulaba hábilmente el doble contratiempo, antes aludido, que en la perspectiva de los liberales mallorquines constituía la voluntad de las Cortes de levantar un monumento funerario al de la Romana, pues le daba la vuelta al sentido del ejemplo, de negativo a positivo, adjudicando, de paso, el siguiente pensamiento al difunto general: «sirviendo mi descanso en campo abierto de ejemplo a todos para que lo sigan sin repugnancia y sin horror» (p. 440), y destruía, a la vez, el tufo de parcialidad que podía interpretarse que destilaba aquella iniciativa de las Cortes de Cádiz, aquel templo del progreso y de las libertades, espejo impoluto en el que continuamente se miraban los reformistas.

De otra parte, trasladaba a la vez Miguel Domingo en ese su escrito un compromiso respecto de la construcción del cementerio de Palma que, por las razones que fueran, no se cumplió: «La Aurora por su parte, y vd. por la suya, procurarán dar movimiento a esta obra» (p. 440); puesto que, por lo que sabemos, no se volvió a comentar nunca más ese asunto en el periódico ${ }^{47}$.

Ignoramos también cuál fue la causa de la tardanza del Semanario Cristiano-Político de Mallorca, siempre tan atento a combatir las opiniones de la Aurora, en abordar una materia respecto de la que se mantuvo en silencio hasta su número 12 , de 15 de octubre de $1812^{48}$. En esta fecha se lanza por fin a la arena de la lucha aparentando un tono de desenfado, pues aprovecha el artículo de la

\footnotetext{
${ }^{47}$ Sí asoma el tema, es cierto, aunque de pasada y no suscitado por la redacción del periódico, sino por «El suspicaz», en la Aurora Patriótica Mallorquina, n 85, de 8 de agosto de 1813, en un texto sobre el que más tarde volveremos.

${ }^{48}$ Aunque de forma indirecta, socarrona y hasta simbólica, sí que lo había traído, de algún modo, a colación el Semanario Cristiano el 24 de setiembre, $\mathrm{n}^{\circ}$ 9, en su impugnación al escrito firmado por «La verdad» en la Aurora el 14 de setiembre, y en el que, conforme ya dejamos consignado, se hablaba sobre la fiebre amarilla que castigaba la Península, así como de los medios para contenerla: «Pero ya que le ha dado la gana de declamar contra pestes y contagios, podría haberlo hecho, y con más acierto, comunicando un artículo semejante a la Aurora sobre el contagio pestilencial que este
} 
Aurora del 15 de setiembre - que nosotros, como ellos, atribuimos a Isidoro de Antillón-, para, apropiándose de una gran parte de su sintaxis y vocabulario, darle la vuelta a los argumentos pro domo sua ${ }^{49}$. Como muestra transcribimos el siguiente fragmento, que puede ponerse en comparación con el más atrás recogido de la Aurora:

Uno de los artículos más útiles que Vd. podría insertar en su Semanario sería sobre los cementerios, demostrando que es muy exagerado el perjuicio que recibe la salud pública de la piadosa y antigua costumbre, introducida generalmente en esta Isla de enterrarse los cadáveres en el recinto del templo y bajo de los pies del pueblo, allí reunido para orar a Dios por vivos y difuntos (p. 137).

Al igual que acontecía cuando se trataba de mentar la Constitución u otras normas legislativas vigentes, los redactores del Semanario Cristiano, así como otros muchos reaccionarios, ponían buen cuidado, en el acto de dejar constancia escrita de sus ideas, en no atacar frontalmente tales disposiciones legales, sino que, por el contrario, a pesar de su radical oposición a la mayor parte de ellas, se empeñaban a menudo, sin regatear en floridos encajes retóricos, en retorcer su significado para intentar adaptarlo a sus particulares puntos de vista. Así ocurre ahora, donde se dice que la loable práctica de enterrar en las iglesias ha sido «combatida últimamente por todos los sofismas, con que han intentado sorprender las rectas intenciones del gobierno» (137). Esto es, el Semanario Cristiano no refuta las disposiciones de la autoridad en esta materia, sino la distorsionada interpretación que, a su juicio, efectuaban algunos liberales de las mismas.

Por si fuera poco, el reseñado periódico recababa de las autoridades religiosas un mayor celo en la lucha contra el tipo de medidas propugnadas en la Aurora, puesto que, según ellos, lo que parece representar una simple cuestión de profilaxis no es sino una embestida más por parte de los liberales contra la Iglesia: «Yo extraño cómo permiten las autoridades eclesiásticas, y cómo se deja impunemente libre la carrera a escritos tan malignos, y que no se desfoguen más los ministros del evangelio en la catedra del Espíritu Santo» (p. 138).

Con toda la razón, por tanto, podrá Miguel Oliver sentenciar que: «La paternidad de la idea le dio color de conflicto religioso; y de su índole puramente higiénica convirtiose en cuestión de impiedad ${ }^{50} \gg$. Y ello, con la aclaración, que

maligno meteoro pretende introducir en esta Isla, por lo relativo a religión y moral» («Señor editor del Semanario», sin firma, p. 109).

${ }^{49}$ El mismo título: «Antítesis a la Aurora núm. 93» y rúbrica: «El enemigo del Aurorismo (no por artífrasis [sic])» dan razón de ese propósito.

${ }^{50}$ OLIVER, op. cit., p. 145. 
el propio Oliver acertadamente señala, de que únicamente una parte del clero se oponía a la utilización de los cementerios.

Una semana más tarde, en su siguiente número, el Semanario Cristiano de 22 de octubre de 1812 retoma otra vez la polémica, pretendiendo invalidar con hechos contrastados las tesis proclamadas en la Aurora sobre el sitio más adecuado para dar sepultura a los muertos. El anónimo autor del nuevo «Artículo comunicado», con el que se pretende rebatir otra vez el publicado en la Aurora el 15 de setiembre, asentaba sus razonamientos, así en la historia, asegurando que de las seis epidemias sufridas en Mallorca, ninguna había tenido su origen en la isla, como, sobre todo, en la realidad circundante, «para escuchar razones, atengámonos a la experiencia». Punto sobre el cual aduce que, con resultar las de Sto. Domingo y San Francisco las iglesias en las que más cadáveres se entierran, y acudir los frailes a ellas adscritos a rezar en horas en que se encuentran cerradas, y por ende peor ventiladas, ninguno de estos males han sufrido estos en sus personas, sino, al revés, pues «¿en dónde se goza de más salud, que en estos dos conventos?» (p. 148). Dichos argumentos le valen al comunicante para achacar a falacia liberal las presuntas enfermedades ocasionadas por inhumar los cuerpos dentro de los templos: «que así como hay sofismas teológicos y metafísicos, los hay médicos, químicos y políticos. Cuando se toman las precauciones correspondientes, como se toman en Mallorca, cuanto se alega de la medicina, química, y policía es sofístico ${ }^{51} \gg$ (p. 150).

En consonancia con tales premisas, ya a finales del siglo XVIII, se había expresado del modo siguiente - con el correspondiente recado de inconsistencia para los que sostenían la postura contraria - el jurista Marcos Antonio de Orellana: «Algunos modernos fundados en imaginarias razones físicas han pensado si podía ser dañoso a la salud el enterrarse los difuntos en las Iglesias, por los hálitos pútridos que puedan despedir las sepulturas ${ }^{52} \gg$. Argüía Orellana, a continuación de lo anterior, cómo lejos de constituir una amenaza: «solo digo, que nunca se han experimentado menos epidemias que en estas centurias» (pp. 392-393), tal práctica se erigía en una fuente constante de ventajas y beneficios para todos: «cuya loable costumbre de enterrarse en las Iglesias produce a vivos, y difuntos inefables bienes, y conveniencias» (p. 393). Y pretextaba, además, en defensa de ese método el que rara vez ocasionaba malos olores, «pues ya tienen a este fin las

\footnotetext{
${ }^{51}$ A pesar de estas palabras, no parece que la ciudad de Palma, si nos atenemos al panorama que dibuja Miguel Oliver, se alzara como modélica en este género de cuidados: «Muchas iglesias hedían de un modo insoportable; las sepulturas mal cerradas causaban frecuentes hundimientos y desgracias en días de concurrencia» (p. 644).

${ }^{52}$ ORELlANA, M. A. de. (1923). Valencia antigua y Moderna. Valencia: Acción Bibliográfica Valenciana, t. I, p. 392 (el texto manuscrito del autor data del último tercio del siglo XVIII). PingarrónEsaín ya mencionaba en su artículo antes citado (p. 118) la opinión de Orellana sobre este tema.
} 
Iglesias (al menos en Valencia) prevenido yeso para amazado [sic] ponerle en las grietas y aberturas de las lozas [sic]» (p. 393).

Volviendo al Semanario Cristiano, ha de señalarse que no dio con aquel número el asunto por zanjado, pues todavía en el siguiente, el 14, de 29 de octubre, insertará aquella misiva del obispo de Menorca, a la que ya antes aludimos, y que había dado lugar a polémica propia; cosa que utilizará ahora el hebdomadario para proseguir con sus mandoblazos a la Aurora y a su editor: «Que conozca el pueblo mallorquín a esta propaganda, y no dé oídos a sus perversas doctrinas, es el fin, que nos hemos propuesto ${ }^{53} \gg$ (p. 163).

No obstante las opiniones del Semanario Cristiano, parecía existir, al menos en un sector de la ciudadanía de Palma, una cierta ilusión en lo que se refería a la limpieza e higiene municipal que se esperaba habría de fomentar el nuevo Ayuntamiento constitucional, encabezado por Nicolás de Armengol; de ello da testimonio el artículo «Al nuevo Ayuntamiento Constitucional», firmado por «El Amante del orden», insertado en el Diario de Palma de 13 de diciembre de 1812 , $n^{\circ} 99$. Sin embargo, las expectativas debieron de superar a lo que la realidad finalmente acabó deparando, puesto que si atendemos al, ya antes citado artículo de la Aurora Patriótica de 8 de agosto de 1813, $\mathrm{n}^{\circ} 85$, en la capital de las Baleares se había adelantado bien poco en materia de salubridad pública en general, y más concretamente en el tema de los enterramientos: «¡cuántos peores efluvios no están produciendo las alfarerías, los hornos de yeso, y sobre todo las sepulturas y sin embargo no llegan al sensorio común de ...». Y unas líneas más adelante, incidía de nuevo: «los cementerios olvidados contra las órdenes del gobierno» (p. 316).

\section{EL DESENLACE DE LA CUESTIÓN}

Aunque los liberales acabaron saliéndose con la suya, la cosa llevó su tiempo. Así, a la altura del 18 de octubre de 1813, en una sesión de las Cortes, Antillón, en su calidad entonces de diputado, propuso que se instara al Gobierno a fin de que decretara las órdenes más terminantes en relación a la exacta observancia de las leyes que prohibían los enterramientos dentro de las poblaciones, y que se hiciera particularmente responsable a cualquier autoridad que intentara entorpecer la ejecución de tal disposición ${ }^{54}$. Dicha sugerencia dio origen a una

\footnotetext{
${ }^{53}$ Finalmente, y bien que de modo muy tangencial, en el Semanario Cristiano de 29 de abril de $1813, \mathrm{n}^{\circ}$ 41, a través de un artículo dirigido por Y. G. R. «Al Procurador General de la nación y del rey», pp. 194-195, encontramos un último rastro del asunto, mediante una broma construida sobre la comparación entre el peligro del contagio físico y el de las nuevas ideas liberales.
}

${ }^{54}$ (1813). Actas de las Cortes ordinarias del año de 1813. Cádiz: Imprenta Nacional, p. 85. 
comisión del Congreso, la cual, más de un mes después, el 29 de octubre de 1813, dictaminó a favor de aquella proposición, con la nota de que debía concederse el plazo de un mes «para que puedan tomarse las disposiciones necesarias a preparar los cementerios provisionales fuera de poblado, y en parajes ventilados mientras se concluyen los permanentes». Acerca del tipo de sanción que podría recaer en quien contraviniera tal disposición, el «señor Cepero ${ }^{55}$ » propuso que «a los eclesiásticos que se opusieren se les ocupen las temporalidades, y a los religiosos se les imponga la pena decretada en 16 del corriente a los prelados de S. Juan de Dios ${ }^{56}$ \%.

Finalmente, fechada el 1 de noviembre de 1813 en la Isla de León, las Cortes emitieron, a través de la Regencia del Reino, una orden tajante instando a todos los jefes políticos provinciales para que hicieran cumplir las leyes (allí donde no se estuviera llevando a cabo) «que prohíben los enterramientos dentro de poblado $[. .]$.$» , y ello con el apercibimiento expreso de que «cualquiera autoridad,$ sin distinción de clase, que intentare entorpecer la ejecución de esta tan urgente y saludable disposición, será personalmente responsable ${ }^{57}$ ». A la vez, urgía el Congreso de los diputados a tener preparados, en el plazo de un mes, los cementerios provisionales, «fuera de poblado y en parajes ventilados» (p. 16), mientras se llevaban a cabo los definitivos ${ }^{58}$.

En Palma de Mallorca no tardó en darse cumplimiento a ese mandato, cuestión a la que quizá no fuera ajena la circunstancia de que un renombrado liberal mallorquín, persona muy cercana a la Aurora Patriótica y a su ideario, Guillermo Ignacio de Montis, había sido nombrado jefe político superior de las Baleares en el mes de setiembre de 1813.

Sea de esto lo que fuere, el caso es que el cementerio palmesano de Son Tritlo comenzó a funcionar el 5 de enero de 1814, según consigna Miguel Oli$\operatorname{ver}^{59}$, en una fecha que, a juzgar por la «Anécdota» contenida en el Diario de Ma-

${ }^{55}$ Manuel López del Cepero, cura del sagrario, fue, como es sabido, autor de un folleto que levantó ampollas entre los retrógrados, $A$ Sevilla libre, publicado en 1812 en Cádiz, y reimpreso ese mismo año en Mallorca por Miguel Domingo.

${ }^{56}$ Actas de las Cortes, op. cit., p. 157.

${ }^{57}$ (1822). Colección de los decretos y órdenes que han expedido las Cortes ordinarias desde 25 de setiembre de 1813, día de su instalación, hasta 11 de mayo de 1814, en que fueron disueltas. Madrid: Imprenta Nacional, t. V, p. 15.

${ }^{58}$ Con algo de retraso, y dentro del habitual epígrafe «Cortes», se reseña en el Diario de Palma de 26 y 27 de diciembre de 1813 (números 110 y 111, p. 445 y p. 450, respectivamente) este concreto punto, tratado en la sesión de las Cortes del día 29 de octubre.

${ }^{59}$ Op. cit., p. 644. 
llorca de 9 de enero de 1814, creemos más exacta que la apuntada por Llabrés ${ }^{60}$, quien remitiéndose a Bover la fija dos días después, en el sábado 7 de enero ${ }^{61}$. Precisamente Llabrés, apoyándose ahora en los datos de un manuscrito de José Climent (Notas del mando del primer jefe político [...]), recoge diversos aspectos de un Reglamento para la correcta utilización de los cementerios que circulaba en un folleto de 8 páginas y 18 artículos, impreso por Miguel Domingo, fechado el día 3 de enero de 1814, y refrendado por el mencionado Montis.

Del breve extracto transcrito por Llabrés, entresacamos unas reflexiones, en las que, tras hacer mención del largo periplo sufrido para hacer que la ley fuese obedecida: «Ya queda cumplido en esta ciudad y en la mayor parte de los pueblos de la isla el decreto de las Cortes sobre enterramientos fuera de poblado, tantas veces mandado, siempre eludido y puesto por fin en ejecución» (ibídem, p. 433), advertimos que no omite, tampoco, la crítica hacia posiblemente cierto sector del clero - pero sin nombrarlo_- al que parece hacer responsable de aquella tardanza, y a la vez nos informa del sentimiento del pueblo llano, igualmente contrario a tal práctica innovadora: «La ignorancia supersticiosa y el egoísmo interesado de ciertas clases de la sociedad han trabajado lo bastante, pero en vano para diferirlo [...], y espero que la repugnancia que el vulgo manifiesta en el día, disminuirá progresivamente, siempre que los que dirigen su opinión no la extravíen en tan importante materia» (ibídem, pp. 433-434).

Pero como es natural, y por más ordenanzas que se promulgaran, siempre cabía el resquicio para transgredir o sortear algunos puntos de la ley. Así lo declara, pocos meses después de la entrada en vigor del nuevo sistema, el editor del Diario Político y Mercantil de Palma — quizá la misma persona que su impresor, Miguel Domingo - , cuando refiere el abuso observado, especialmente en los largos días estivales, para con el bando municipal sobre enterramientos fuera de poblado, que estipulaba que los cuerpos habían de llevarse a la sepultura al amanecer o al anochecer. De ahí que, ante dicha conculcación normativa, se obligue a sí mismo el mencionado editor a denunciar tales hechos públicamente, cuantas veces resulte necesario: «Las facultades del editor no se extienden a contener a los infractores en los límites de la más rigurosa obediencia, pero protesta que seguirá haciendo con frecuencia recuerdos de esta especie hasta que lleguen a oídos de los que tienen en su mano hacerse respetar $\left.^{62}\right\rangle$.

\footnotetext{
${ }^{60}$ Op. cit., t. I, p. 433

${ }^{61}$ «El día de Reyes al retirarse la gente de la procesión de Jesús había junto a la Misericordia un carro parado con un difunto dentro para llevarle al cementerio» (Diario de Mallorca de 9 de enero de $1814, n^{\circ} 8$, p. 35).

62 «Nueva reclamación sobre entierros» (sin firma), en el Diario Político y Mercantil de Palma, $\mathrm{n}^{\mathrm{o}} 104$, de 15 de abril de 1814, p. 3. El redactor principal de este periódico durante esas concretas
} 
Y es que el camino había sido demasiado largo y muy grande el esfuerzo de aquel puñado de ciudadanos comprometidos con el progreso, en aras de conseguir un avance de la salubridad pública en beneficio de la ciudadanía, para que a las primeras de cambio se bajara la guardia o se mirara para otro lado ante una incorrecta utilización que pudiera menguar en mucha parte la eficacia profiláctica del nuevo método.

En conclusión, la sempiterna dicotomía - tan inherente a la naturaleza de los seres humanos que los acaba dividiendo y enfrentando - entre la seguridad de encastillarse en lo conocido y conducirse por pautas tradicionalmente consagradas, o el riesgo de aventurarse a salir de ese universo cotidiano para arriesgarse a conseguir algo mejor, terminó por fraguar una nueva controversia en este asunto de los enterramientos, entre rancios y liberales.

Estos últimos, por su parte, como gentes más desligadas de pretéritos condicionamientos o de dependencias e inclinaciones hacia hábitos antiguos, y con las miras siempre puestas en la modernización nacional, ya fuera en materia política, religiosa, o de higiene pública, se van a erigir, en estos primeros años del siglo XIX, en abanderados del traslado de las sepulturas desde los templos a los cementerios; especialmente en un tiempo en que una epidemia de fiebre amarilla deambulaba por la Península provocando el temor de las gentes.

En esto, como en tantas otras cosas, conservaban los liberales aquel espíritu ilustrado que tan notablemente había contribuido a desfacer viejas supersticiones y a procurar el adentramiento en el conocimiento científico, muy del gusto, conforme hemos visto, de hombres como Isidoro de Antillón y Miguel Domingo; un método lógico, hijo de la razón, que propiciaba, en definitiva, el adelanto en las más variadas disciplinas.

Progreso, sí, pero únicamente en la propia interpretación de los renovadores, porque para la facción contraria aquello mismo suponía un considerable retroceso, como bien se encargó de denunciar el Semanario Cristiano de 18 de noviembre de $1813, \mathrm{n}^{\circ} 70$, reproduciendo un artículo de otro periódico del bando servil: la Atalaya de la Mancha, titulado «La religión defendida» y firmado por «M. V.»: «Vengamos al siglo último, que el libertino llama siglo de ilustración y de luces, y la religión puede nombrar siglo de impiedad y de tinieblas. Iglesia santa: ¡qué de enemigos te combaten!» (p. 607).

De ahí que la pasión que los liberales ponían por remozar viejas usanzas patrias no dejaba de chocar una y otra vez contra ese muro reaccionario empeñado, por encima de todo, en no ceder un ápice en materia de costumbres y tradición, y permanecer por siempre anclado en las prácticas antañonas, equivalentes

fechas posiblemente fuera Joaquín Pérez de Arrieta. 
para ellos a un certificado de españolismo: «Embrutecimiento, ¡Eh! Ya os conocemos filósofos liberales; sí: ya os conocemos: ojalá quisieran también conocer Vds. que a los mallorquines verdaderos patriotas nos va bien y muy bien con este tal embrutecimiento; y que si no queremos, ni permitiremos jamás que unas manos sucias vengan a limpiarnos $\left.{ }^{63}\right)$.

Respecto de la sustitución de las iglesias por los cementerios como lugar de enterramiento, ha de significarse que ignoramos si el origen del rechazo que, en términos generales, produjo en los más conservadores vino causado por la propia actividad de sepultar fuera de los templos, o solamente por el hecho del cambio en sí, esto es, por lo que aquello tenía de nueva mudanza en los viejos hábitos, de otro tanto que añadir en el haber de los liberales y, paralelamente, de un paso atrás en su frente de batalla, otro menoscabo más infligido por las Cortes de Cádiz a las usanzas seculares.

Y si bien se mira, probablemente el motivo de su oposición fuera más bien esto último. Entre los elementos que contribuyen a pensar en esa dirección, se cuenta el contenido de una circular del Consejo Real, fechada el 30 de junio de 1814, es decir, con un gobierno despótico rigiendo de nuevo los destinos de España, en la cual se instaba a las diversas autoridades del Estado a practicar las inhumaciones en los cementerios, cuestión que según advierte es para ellos ahora «un asunto que tanto interesa al bien general ${ }^{64 »}$, y recuerda al efecto las providencias adoptadas por S.M. en 1787 y 1804 (a lo largo de este trabajo ya aludidas), es decir, las relativas a la época absolutista, obviando, sin más, el resto de disposiciones, esfuerzos y trabajos llevados a cabo en tal sentido durante los largos años de la guerra contra el francés ${ }^{65}$.

\footnotetext{
${ }^{63}$ Semanario Cristiano de 19 de agosto de 1813, no 57, p. 387, n. 33, «Prosigue el artículo remitido al señor Tribuno», de la posible autoría de fray Raimundo Strauch.

${ }^{64}$ Citamos por el texto de dicho documento insertado en el Diario de Mallorca de 19 de julio de $1814, \mathrm{n}^{\circ} 150$, pp. $828-829$, p. 828.

${ }^{65}$ Aunque el hecho de haber sido dictadas estas disposiciones legales en favor de los cementerios extramuros por un Gobierno reaccionario no significó necesariamente que fuesen universalmente acatadas, ni siquiera existiendo afinidad ideológica entre la autoridad de la que dimanaban y los subordinados que habían de ejecutarlas, puesto que todavía vetustas inercias predisponían, como ya más atrás hemos dejado de manifiesto, a que en algunos lugares se mantuvieran las usanzas antiguas durante bastantes años más.
} 